\title{
B-vitaminet folat og svangerskap
}

\author{
Stein Emil Vollset ${ }^{1,2}$, Roy M. Nilsen ${ }^{1}$ og Anne Kjersti Daltveit ${ }^{1,2}$ \\ 1) Institutt for samfunnsmedisinske fag, Universitetet $i$ Bergen \\ 2) Medisinsk fødselsregister, Nasjonalt folkehelseinstitutt \\ Korrespondanse: Stein Emil Vollset, Institutt for samfunnsmedisinske fag, Universitetet i Bergen, Postboks 7804, 5020 Bergen \\ Telefon: 55588531 E-post: vollset@uib.no
}

\begin{abstract}
Etter at forskning på begynnelsen av 1990-tallet viste at B-vitaminet folat (også kalt folsyre; tidligere folinsyre) alene eller sammen med multivitaminer kunne redusere forekomsten av enkelte medfødte misdannelser, ble det i Norge et økende fokus på folat og svangerskap. I 1996 ble situasjonen rundt helse- og ernæringsmyndighetenes håndtering av folat-problematikken betegnet som "sikker kunnskap, usikker praksis" (1). Vi skal i det følgende forsøke å beskrive situasjonen 11 år senere. Noen spørsmål er avklart, andre er kommet til, praksis er klart endret, resultatene har latt vente på seg, og det knytter seg fortsatt usikkerhet til hva som er den beste helsepolitikken på dette området.
\end{abstract}

\section{ET VITAMIN SOM FOREBYGGER ALVORLIG SYKDOM}

Europeiske forskere viste i 1991 og 1992 at folat alene eller sammen med multivitaminer kunne mer enn halvere risikoen for ryggmargsbrokk og andre beslektede alvorlige medfødte misdannelser (nevralrørsdefekter). En forutseting for at folat skal ha denne forebyggende effekten er at man starter å ta folattilskudd før man blir gravid og forsetter i svangerskapets første måneder. Det er ikke tilstrekkelig å spise matvarer som er rike på folat (brokkoli, spinat, appelsiner, dypgrønne grønnsaker, rosenkål, grove kornvarer, fersk gjær, leverprodukter) - et tilskudd på $0,4 \mathrm{mg}$ folat daglig er nødvendig for full beskyttelse. Med denne kunnskapen reagerte amerikanske myndigheter med rekordfart og anbefalte folat-tilskudd til alle kvinner i fruktbar alder og man vedtok obligatorisk beriking av mel og melprodukter i hele USA fra 1997. På det amerikanske kontinentet har i tillegg en rekke andre land inkludert Canada, Chile, Brasil og Argentina startet obligatorisk beriking av mel. Både i USA, Canada og Chile har man observert fall i forekomsten av ryggmargsbrokk, som kan knyttes til tidsperioden man innførte beriking med folat.

I Norge og andre europeiske land (blant andre Storbritannia og Sverige) har man diskutert og vurdert folatberiking, men så langt konkludert med at usikkerhet omkring mulige bivirkninger av folat tilsier at man avventer innføringen av dette tiltaket. I Norge har arbeidsgrupper under Nasjonalt råd for ernæring utarbeidet tre rapporter om folatspørsmålet (i 1998, 1999 og 2005). De to første ledet frem til en anbefaling om et folattilskudd på $0,4 \mathrm{mg}$ hos kvinner som planlegger graviditet. Den tredje rapporten skulle evaluere denne anbefalingen og ledsagende opplysningskampanjer, og spesielt ta stilling til spørsmålet om beriking av matvarer med folat. Man nådde ikke noen klar konklusjon på det siste punktet, men utsatte beslutningen i påvente av resultater fra de norske kliniske utprøvingene av folat hos pasienter med hjertesykdom $(2,3)$.
I Sverige var det først bekymring om at folat kunne gi økt forekomst av tvillingsvangerskap som hindret et vedtak om beriking (tvillingsvangerskap er uønsket fordi risikoen både for barn og mor er betydelig høyere enn ellers). Senere, til dels basert på nyere svenske epidemiologiske undersøkelser, er det bekymring for at folat kan stimulere vekst av kreftsvulster som har vært hovedgrunnen til å vente $(4,5)$. En randomisert studie fra USA har et bifunn som peker i samme retning (6). I Storbritannia har man i flere år arbeidet for å innføre berikning. Våren 2007 diskuteres dette på nytt basert på en stor og grundig britisk vitenskapelig utredning av folatspørsmålet (7). Den britiske rapporten hevder av bekymringen for at folatberiking skal kunne fremme vekst av kreftsvulster er basert på et så svakt grunnlag at den ikke bør hindre et vedtak i saken. Det er ventet at Storbritannia fatter en beslutning om spørsmålet i løpet av 2007. Så langt har kun ett europeisk land, nemlig Irland, besluttet obligatorisk beriking av matvarer (brød) med folat.

\section{FOLAT OG KRONISK SYKDOM HOS VOKSNE OG ELDRE}

I tillegg til å kunne forebygge medfødte misdannelser har folat fått oppmerksomhet fordi det effektivt senker blodnivået av homocystein. Homocystein er en aminosyre som kan måles i blodet og som de siste 15 årene har vist seg å være en sterk risikofaktor for hjertekarsykdom. De siste årene er det blitt klart at også pasienter med aldersdemens, osteoporose og osteoporotiske brudd har forhøyede homocysteinnivåer. På denne bakgrunnen ble det $\mathrm{i}$ en rekke land igangsatt behandlingsforsøk med folat og andre B-vitaminer (vitamin B12 og i noen tilfeller vitamin B6) hos pasienter med hjertekarsykdom. Resultatene så langt viser at Bvitamintabletter ikke er noen effektiv behandling $\mathrm{i}$ denne pasientgruppen. To store randomiserte studier har vært gjennomført i Norge. NORVIT (Norwegian Vitamin trial) viste ingen bedring hos pasienter som fikk behandling med folat, vitamin B12 eller vitamin 
B6 etter akutt hjerteinfarkt (8). I pasientgruppen som fikk alle tre B-vitaminene var det endog tegn til ugunstig effekt av behandlingen. WENBIT (Western Norway B-vitamin Intervention Trial; ClinicalTrials.gov Identifier: NCT00354081) er den andre store norske studien som forsøker B-vitaminbehandling hos hjertepasienter. Den er gjennomført ved universitetssykehusene i Bergen og Stavanger. De første hovedresultatene fra studien vil bli publisert i 2007 eller 2008.

\section{Folat I NORGE - MEDISINSK FØDSELSREGISTER}

Fordi man hadde ny kunnskap om at vitaminer kan være viktige i svangerskapet, ble spørsmål om bruk av folat og vitamintilskudd tatt inn i det reviderte meldeskjemaet for fødsel som Medisinsk fødselsregister (MFR) tok i bruk i desember 1998. I dette skjemaet skal det rapporteres om mor tok kosttilskudd i form av folat eller multivitaminer før eller under svangerskapet. Hensikten med å inkludere denne informasjonen $\mathrm{i}$ meldeskjemaet var for det første å få en oversikt over bruken av folat i tilknytning til svangerskap og for det andre å kunne vurdere helseeffekter av mors inntak av folat før og under graviditeten.

Tall fra Medisinsk fødselsregister for året 2004 viser at $16 \%$ av kvinnene tok folat før svangerskapet, mens $40 \%$ tok folat under svangerskapet (foreløpige tall for 2005 viser en ytterligere økning til henholdsvis 19\% og 45\%). Før 1998 var bruken av folattilskudd nær null i Norge - dels fordi folatanbefalingene ikke var kommet enda og dels fordi folat ikke var til salgs $i$ riktig dose på $0,4 \mathrm{mg}$. Slik sett representerer de siste tallene et betydelig fremskritt, men bruken, spesielt $\mathrm{i}$ den kritiske perioden før svangerskapet, er fortsatt for lav til at man kan forvente noen stor nedgang i nevralrørsdefekter på nasjonal basis.

For å kartlegge bruk av og holdninger til folat i tilknytning til svangerskap i større detalj, gjennomførte Statistisk Sentralbyrå i 1998 og 2000 i regi av et samarbeid mellom Nasjonalt råd for ernæring og Medisinsk fødselsregister to spørreundersøkselser blant et utvalg av norske kvinner i fertil alder (9). Både kunnskapen om folat, bruk av folattilskudd og ønske om å bruke folat i tilknytning til svangerskap økte markant mellom de to undersøkelsene. I den siste undersøkelsen var det blant kvinner som nylig hadde født, som var gravide eller som planla graviditet, $67 \%$ som hadde kunnskap om anbefalingene, og hele $87 \%$ var positive til bruk av folattilskudd i fremtidige svangerskap. Til tross for at norske kvinner både har god kunnskap og høy motivasjon, viser imidlertid data fra en rekke kilder at det er få kvinner som bruker folat riktig. Det største problemet er at kvinnene starter for sent med tilskudd av folat. Fordi nevralrøret lukkes allerede tre uker etter konsepsjonen må kvinnen, for å forebygge ryggmargsbrokk, starte med inntak av folat i praksis før hun vet at hun er gravid.
I en studie basert på data fra Den norske mor og barn undersøkelsen ble inntak av folat-tilskudd undersøkt i detalj blant 22500 gravide kvinner for årene 2000-2003 (10). Studien viste at omtrent 70 prosent av de gravide kvinnene hadde tatt folat på et eller annet tidspunkt mellom 2 måneder før svangerskapet og 8 måneder ut i svangerskapet. Av disse hadde mer enn 50 prosent startet bruken for sent $\mathrm{i}$ forhold til tidspunktet for lukking av neuralrøret. Kun 1 av 10 kvinner hadde tatt folat regelmessig i hele den anbefalte perioden. Videre viste studien at den regelmessige folatbruken var lavest hos kvinner med grunnskole som høyeste utdanning. Bruken var også meget lav blant de yngste kvinnene, kvinner med flere tidligere svangerskap, samt blant kvinner som ikke hadde planlagt svangerskapet.

\section{ANDRE ARBEIDER MED NORSKE DATA}

I en internasjonal studie som dekket 13 millioner fødsler i 10 land mellom 1992 og 1998, og hvor Norge deltok, kunne man ikke finne noen sammenheng mellom anbefalinger om økt folatinntak (vanligvis med folattilskudd i tablettform) og redusert forekomst av nevralrørsdefekter (11). Som den siste folatutredningen i regi av Nasjonalt råd for ernæring (2), konkluderte artikkelen med at kun beriking av matvarer med folat kan gi synlig fall i medfødte misdannelser i befolkningen. Norge deltok også i en annen stor europeisk studie, med data fra 34 registre i 18 land for perioden 1980 2002, som kom til en tilsvarende konklusjon (12).

Fordi blant annet rapporter fra Sverige hevdet at folatbruk kunne gi tvillinger, ble dette spørsmålet undersøkt med data fra Medisinsk fødselsregister (13). I utgangspunktet var funnene i Norge lik de svenske: kvinner som tar folat har 70\% høyere forekomst av tvillingsvangerskap enn andre. Studien kunne imidlertid vise at dette ikke skyldtes selve folatbruken, men langt høyere bruk av prøverørsbefruktning hos kvinner som tar folat. Fordi politikken har vært å implantere flere befruktede egg ved kunstig befruktning fremkom denne tilsynelatende effekten av folat på tvillinger. Etter at prøverørsbefruktning ble tatt hensyn til var det ingen sammenheng mellom folat og tvillinger.

Nylig er det ved hjelp av en stor norsk pasientkontrollstudie på leppe-ganespalte vist at lavt inntak av folat er en risikofaktor for å få et barn med leppeganespalte (14). Dette er et viktig resultat fordi det støtter tidligere studier som har vist at folat ikke bare forebygger ryggmargsbrokk og andre nevralrørsdefekter, men også andre typer medfødte misdannelser.

\section{KONKLUSJON}

Vi vet mer enn noensinne om folat og sykdom. Det er ikke vist at folat er gunstig behandling hos pasienter med hjertekarsykdom eller andre alvorlige sykdommer. Det er fortsatt et åpent spørsmål om et høyt folatinntak tidlig i livet eller i ung voksen alder kan fore- 
bygge hjertekarsykdom. Det er et vitenskapelig faktum at folat forebygger ryggmargsbrokk og andre nevralrørsdefekter. Man anbefaler at kvinner som planlegger graviditet tar $0,4 \mathrm{mg}$ daglig før og i svangerskapets første måneder. Det er etter hvert klart at man med en slik anbefaling alene ikke oppnår maksimal reduksjon av nevralrørsdefekter i befolkningen. Usikkerhet omkring mulige bivirkninger av folat hos andre enn gravide har ført til at mange europeiske land (også Norge) i motsetning til USA og andre land på det amerikanske kontinent, foreløpig ikke har innført obligatorisk beriking av matvarer med folat.

\section{REFERANSER}

1. Vollset SE, Irgens LM. Folinsyre og svangerskap - sikker kunnskap, usikker praksis (leder). Tidsskr Nor Lageforen 1996; 116: 217-8.

2. Staff AC, Løken EB, Holven K, Sygnestveit K, Vollset SE, Smeland S. Effekt av offentlige tiltak for å forebygge nevralrørsdefekter med folat. Tidsskr Nor Lageforen 2005; 125: 435-7.

3. Staff AC, Holven K, Løken EB, Sygnestveit K, Vollset SE, Smeland S. Effekt av folat på andre helseproblemer enn nevralrørsdefekter? Tidsskr Nor Lageforen 2005; 125: 438-41.

4. Hultdin J, Van Guelpen B, Bergh A, Hallmans G, Stättin P. Plasma folate, vitamin B12, and homocysteine and prostate cancer risk: a prospective study. Int J Cancer 2005; 113: 819-24.

5. Van Guelpen B, Hultdin J, Johansson I, Hallmans G, Stenling R, Riboli E, Winkvist A, Palmqvist R. Low folate levels may protect against colorectal cancer. Gut 2006; 55: 1461-6.

6. Cole BF, Baron JA, Sandler RS, Haile RW, Ahnen DJ, Bresalier RS, McKeown-Eyssen G, Summers RW, Rothstein RI, Burke CA, Snover DC, Church TR, Allen JI, Robertson DJ, Beck GJ, Bond JH, Byers T, Mandel JS, Mott LA, Pearson LH, Barry EL, Rees JR, Marcon N, Saibil F, Ueland PM, Greenberg ER, for the Polyp Prevention Study Group. Folic acid for the prevention of colorectal adenomas: a randomized clinical trial. JAMA 2007; 297: 2351-9.

7. Scientific Advisory Committee on Nutrition (SACN). Folate and Disease Prevention. London: TSO (The Stationery Office), 2006.

8. Bønaa KH, Njølstad I, Ueland PM, Schirmer H, Tverdal A, Steigen T, Wang H, Nordrehaug JE, Arnesen E, Rasmussen K, for the NORVIT Trial Investigators. Homocysteine lowering and cardiovascular events after acute myocardial infarction. N Engl J Med 2006; 354: 1578-88.

9. Daltveit AK, Vollset SE, Lande B, Øien H. Changes in knowledge and attitudes of folate, and use of dietary supplements among women of reproductive age in Norway 1998-2000. Scand J Public Health 2004; 32: 264 71.

10. Nilsen RM, Vollset SE, Gjessing HK, Magnus P, Meltzer HM, Haugen M, Ueland PM. Patterns and predictors of folic acid supplement use among pregnant women: the Norwegian Mother and Child Cohort Study. Am J Clin Nutr 2006; 84: 1134-41.

11. Botto LD, Lisi A, Robert-Gnansia E, Erickson JD, Vollset SE, Mastroiacovo P, Botting B, Cocchi G, de Vigan C, de Walle H, Feijoo M, Irgens LM, McDonnell B, Merlob P, Ritvanen A, Scarano G, Siffel C, Metneki J, Stoll C, Smithells R, Goujard J. International retrospective cohort study of neural tube defects in relation to folic acid recommendations: are the recommendations working? BMJ 2005; 330: 571-6.

12. Busby A, Abramsky L, Dolk H, Armstrong B, Addor MC, Anneren G, Armstrong N, Baguette A, Barisic I, Berghold A, Bianca S, Braz P, Calzolari E, Christiansen M, Cocchi G, Daltveit AK, De Walle H, Edwards G, Gatt M, Gener B, Gillerot Y, Gjergja R, Goujard J, Haeusler M, Latos-Bielenska A, McDonnell R, Neville A, Olars B, Portillo I, Ritvanen A, Robert-Gnansia E, Rösch C, Scarano G, Steinbicker V. Preventing neural tube defects in Europe: a missed opportunity. Reprod Toxicol 2005; 20: 393-402.

13. Vollset SE, Gjessing HK, Tandberg A, Rønning T, Irgens LM, Baste V, Nilsen RM, Daltveit AK. Folate supplementation and twin pregnancies. Epidemiology 2005; 16: 201-5.

14. Wilcox AJ, Lie RT, Solvoll K, Taylor J, McConnaughey DR, Abyholm F, Vindenes H, Vollset SE, Drevon CA. Folic acid supplements and risk of facial clefts: national population based case-control study. BMJ 2007; 334: 464-9. 